\title{
KNOWLEDGE MANAGEMENT IN ARTIFICIAL INTELLIGENCE BASED AUTOMATED E-MATERIAL FORMATTING TOOL
}

\author{
Kristine Mackare \\ Liepaja University, Latvia \\ Anita Jansone \\ Liepaja University, Latvia
}

\begin{abstract}
Knowledge is a critical resource for scientific, academical and technological development. In a time of fast development and growth of a massive amount of information and big data, knowledge management (KM) has a crucial role in creating knowledge from data and information. Knowledge management discipline increases its popularity among other fastdeveloping disciplines as Artificial Intelligence (AI). It is important to understand how fields of science and technological research and development and knowledge management integrate into each other, cooperate, and support each other. Likewise, understanding theoretical bases in the practical use of knowledge management are crucial for learning and development use. The theoretical part of the publication shortly represents knowledge management theoretical basis. It is followed by a description of the case - artificial intelligence based automated ematerial formatting tool development and research accompanying the development of the tool. The result part of the publication systematically represents knowledge management aspects in the case study. There are included knowledge management aspects as components of knowledge management definition, types, theories, approaches and methods in the case study. Thereby, the publication shows the cooperation of disciplines through the scope of the case study and could be used as a sample in the study process to understand and show knowledge management and knowledge management aspects in the research and development process.
\end{abstract}

Keywords: artificial intelligence, automated formatting tool, e-material formatting, knowledge management.

\section{Introduction}

Knowledge management $(\mathrm{KM})$ is not one single discipline. It is an integration of numerous activities and fields of study (Newman, Conrad, 2000). KM discipline increases its popularity among other fast-developing disciplines as Artificial Intelligence (AI) because knowledge is a critical resource for scientific, academical and technological development.

In two ways, knowledge has been differentiated from data and information. Knowledge is at the top of the hierarchy, with facts in the centre and data at the 
Mackare \& Jansone, 2021. Knowledge Management in Artificial Intelligence Based Automated E-Material Formatting Tool

bottom, according to a more simplistic view (Becerra-Fernandez, Sabherwal, 2010).

In a time of fast development and a huge amount of information and big data, knowledge management (KM) has a crucial role in creating knowledge from data and information.

Theoretical insight of KM basis is shortly represented in the next chapter of the paper. It shows theoretical bases of KM and whose practical use, like in research or development process. It is crucial for the learning process and development use. It allows understanding which methods, approaches, tools, mechanisms, systems and technologies, and other support aspects could and should be used for achieving the goals of development and research.

The case description is presented in the chapter after the literature review. It is a description of artificial intelligence (AI) based automated e-material formatting tool and its development process. It is a practical example of a case study of tool development and research to create KM elements and tool and research cooperation sample.

\section{Literature Review}

Knowledge management (KM) is the process of an organisation's knowledge and information is created, shared, used, and managed (Girard, Girard, 2015) or individualized (Becerra-Fernandez, Sabherwal, 2010). Knowledge management (KM) refers to a multidisciplinary approach (UNC, 2007). In simplest terms, it would be doing whatever it takes to get the best out of information capital and knowledge resources (Becerra-Fernandez, Sabherwal, 2010).

Knowledge types. Declarative knowledge is defined as "knowing what," while procedural knowledge is defined as "knowing how" (Becerra-Fernandez, Sabherwal, 2010). Two types of knowledge are usually defined namely explicit and tacit knowledge (KMT, 2018). Tacit knowledge is action-oriented (procedural) knowledge that is usually acquired without direct help from others (rather by role modelling), and that allows individuals to achieve goals that they personally value (Staudinger, Dörner, 2007). Explicit knowledge (also expressive knowledge) is the knowledge that can be readily articulated, codified, accessed, and verbalised (Definition, n.d.). Many people have the general information, which can be easily transferred from one person to another - it is general knowledge procession. A small number of people only holds specific knowledge, and it is difficult to pass, as well as expensive to transfer (Becerra-Fernandez, Sabherwal, 2010).

Knowledge locations or reservoirs. Knowledge can be found in a variety of places - locations or reservoirs. People and communities or groups are among them, as are artefacts or objects such as procedures, technologies, and 
repositories, as well as organisational entities such as organizational units, associations, organisations and inter-organizational networks (BecerraFernandez, Sabherwal, 2010).

Knowledge management depends on broad aspects: Knowledge management solutions and foundations and knowledge management processes and subprocesses. KM solutions are made up of two parts: knowledge management processes and knowledge management systems. KM strategies are based on three foundations: knowledge management mechanisms, knowledge management technologies, and knowledge management infrastructure (BecerraFernandez, Sabherwal, 2010).

The ways in which particular aspects of KM (discovery, capture, sharing, and application of knowledge) can be achieved are referred to as KM solutions. $\mathrm{KM}$ processes and KM networks are examples of KM solutions. The large organisational aspects that sustain KM in the short and long term are known as KM foundations. They include knowledge management infrastructure, knowledge management processes, and knowledge management technologies (Becerra-Fernandez, Sabherwal, 2010).

$\mathrm{KM}$ processes are the broad processes that aid in the discovery, capture, sharing, and application of knowledge. KM systems and seven distinct types of KM subprocesses - combination, socialisation, externalisation, internalisation, exchange, direction, routines - support these four KM processes.

Either, the four KM processes are supported by KM systems, which are the combination of technologies and frameworks built to support them. Likewise, KM infrastructure supports KM mechanisms and technologies (Becerra-Fernandez, Sabherwal, 2010).

KM infrastructure components are organisational culture, organisational structure, IT infrastructure, common knowledge, physical environment (BecerraFernandez, Sabherwal, 2010). KM mechanisms are defined as the formal and informal mechanisms for sharing, integrating, interpreting, and applying knowwhat, know-how, and know-why embedded in individuals, groups, and other sources of knowledge (Zanjani, Mehregan, 2009). KM technologies are IT that can be used to facilitate KM and focus on KM rather than information processing (Becerra-Fernandez, Sabherwal, 2010). AI technologies are one of those who support KM.

\section{Case Description: Artificial Intelligence Based Automatic E-material Formatting Tool}

The correct and appropriate parameters for e-material text formatting could improve users reading comfort and ocular health. That can be achieved with the automatised e-material formatting tool. This tool can improve the comfort of 
Mackare \& Jansone, 2021. Knowledge Management in Artificial Intelligence Based Automated E-Material Formatting Tool

using e-material in the learning and study process and decrease near workload and reach a reduction of ocular tension. And the goal with the best results could be reached by adapting text formatting for individual needs in addition to appropriate standard parameters.

Primary recommendations for e-material formatting guidelines of the most important typographic aspects were developed for the target group without reading difficulties and without any significant vision problems. A wider overview has presented in previous publications (Mackare, Jansone 2017a; Mackare, Jansone, 2017b; Mackare, Jansone, 2018; Mackare, Jansone, Zigunovs, 2018).

Recommendations of e-material formatting parameters have been developed based on theoretical base and practical research. The theoretical base includes theoretical research on different important processes in human as people development stages of cognitive and visual development, physiological and psychological development, perception, reading, understanding and memory abilities, physiological and psychological capabilities as well as changes in visual system during humans life. To learn more about the habits and subjective preference of users, a practical study was carried out (Mackare, Jansone, 2019b).

After experimental testing of recommendations, those are incorporated in methodology (Mackare, 2021a). Recommendations and methodologies are used for tool development (Mackare, 2021b).

Secondary, the development of pre-development technical documentation has been done before the development of the tool. That includes tool idea and concept, analysis of similar tools, tool development plan, tool using scenario and case description.

The automated e-material formatting tool idea and its working concept are represented in Fig.1. Developers describe the tool and its working process as it is represented further: The tool receives the raw text (1). The document is being transferred through a tool and is being formatted during the formatting process using formatting software (2) and personalised requirements and parameters (3). All specifications as requirements, parameters, criteria, conditions, technological solution, programming, and database are included in formatting software. Requirements include - user needs, personalised formatting, formatting recommendations. After the formatting process, a person gets the formatted and personalised document (4). All data - users' data, users' responses, criteria, requirement, formatting recommendations, users' accumulated data, data accumulated after the machine learning process - should be stored in the database (5). The database serves as both a storage and an active operation. Data is extracted from the database by formatting software (A). It is data for software improvement and a personalised approach to formatting. The formatted and personalised document gives data to the database (B). Users accumulate data after 
using personalised document - reading time, eye movements, memorising abilities, user satisfaction, a decrease of complaints and subjective issues, improvement of ocular functions. Data transport (C) is the connection between the database and the specifications and requirements - personalised requirements and formatting information (Mackare, Jansone, Mackars, 2020b). A wider overview has presented in previous publications (Zigunovs, Mackare, Jansone, 2018; Mackare, Jansone, Zigunovs, 2018; Mackare, Jansone, 2019a; Mackare, Jansone, Konarevs, 2019).

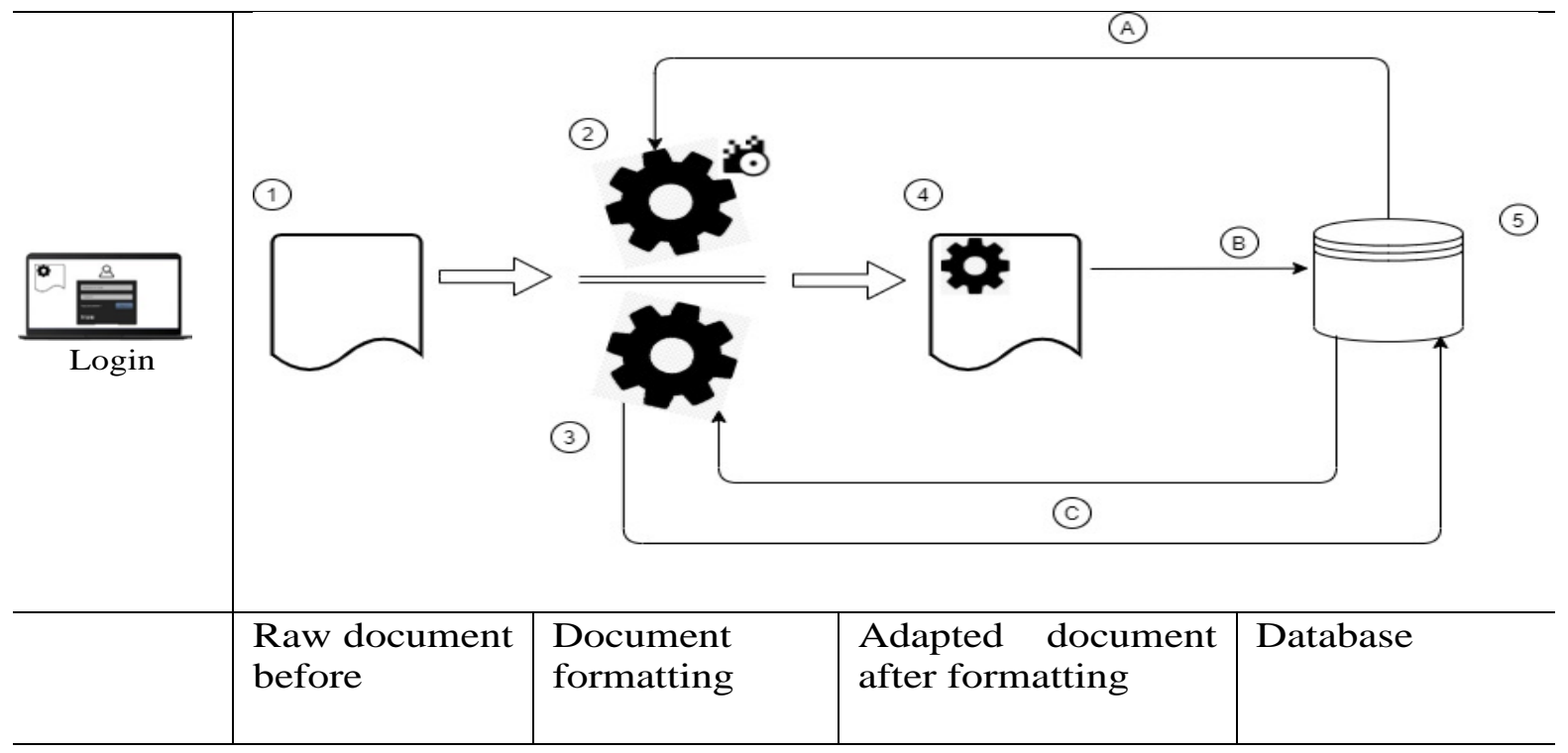

Figure 1 The Application Concept (Mackare, Jansone, Mackars, 2020b)

Thirdly, development of the tool. Includes research of technical solutions, prototype development, testing, changing and improvement of the prototype, AI aspects and $\mathrm{ML}$ incorporation in the prototype.

Prototype 1.0 development. The first developed version of the prototype of the tool gives an overview of the tool. It shows how the tool works to follow implemented working schemes in the development process, represents relationships between the main edges of the tool and the collaboration process of the tool with the user, material, and database as well as collaboration between these main edges (Zigunovs, Mackare, Jansone, 2018). A more in-depth overview of the application prototype was previously written (Zigunovs, Mackare, Jansone, 2018; Mackare, Jansone, Zigunovs, 2018; Mackare, Jansone, 2019a; Mackare, Jansone, Konarevs, 2019).

Conducted preliminary usability testing of tools prototype 1.0. (Mackare, Jansone, Mackars, 2020a).

The tools prototype 2.0 development is focused on improvements of the developed tool. The prototype 2.0 development focus is to make the tool accessible and workable on all the most popular formats of e-materials, primary, 
Mackare \& Jansone, 2021. Knowledge Management in Artificial Intelligence Based Automated E-Material Formatting Tool

MsWord and PDF. For that reason, PHP7.3 programming language has been used as it is chosen suitable for the purpose of the tool and educational environments. Work on the visual appearance of the tool has been done. A more detailed description of the application prototype is published in previous publications (Mackare, Jansone, Mackars, 2020a; Mackare, Jansone, Mackars, 2020b).

AI aspects and ML incorporation in prototype - tool works by using several AI approaches and elements: the connectionist approach, machine learning, Natural Language Processing, perceptron, decision tree graphs, rule-based system, classification, and clustering. It is quite hard to separate each element as they make a tight synergy to reach the best outcome. In tool is a combination of analytical AI and human-inspired AI as it is using learning based on experience to create future decisions and make a decision. AI use in the tool is important for user-centred approach and personalisation as it is connected with the aim of AI to solve problems (Mackare, Jansone, 2019c; Mackare, Jansone, Mackars, 2020c).

Finally, the approbation of tool and final documentation and sharing with results and knowledge must be done. This part is still in progress.

\section{Methodology}

Descriptive analysis of theoretical sources - theoretical materials about knowledge management (KM).

Case study and content analysis - authors materials as artificial intelligence (AI) based automated e-material formatting tool development and previous research accompanying the tool analysis development based on KM aspects described in the theoretical part.

\section{Case Study Results: Representation of Knowledge Management Aspects in Research and Tool Development}

Representation of Knowledge Management definition elements in research

Expansive KM definition contains nine vital elements: coordinated and directed creation of knowledge, accumulation of knowledge, identification of knowledge, application of knowledge, development of knowledge, deepening of knowledge, popularisation of knowledge, dissemination of knowledge and use of knowledge.

During fool research and development pass through different stages and is possible to follow different KM stages and found a wide range of examples of knowledge and KM aspects in it.

Similar elements in scientific research have been found. Examples of those elements in tool development and research have been shown. It is represented in Table 1. Representation of the Different Types of Knowledge in research. 
SOCIETY. INTEGRATION. EDUCATION

Proceedings of the International Scientific Conference. Volume V, May $28^{\text {th }}-29^{\text {th }}, 2021.379-390$

Table 1 Representation of Knowledge Management Definition Elements in Research

\begin{tabular}{|c|c|c|}
\hline $\begin{array}{l}\text { Knowledge } \\
\text { Management }\end{array}$ & Scientific research & Tool development and research \\
\hline $\begin{array}{l}\text { Coordinated and } \\
\text { directed creation } \\
\text { of knowledge }\end{array}$ & $\begin{array}{l}\text { The systematic } \\
\text { Research process is } \\
\text { oriented on results; } \\
\text { data collecting process }\end{array}$ & $\begin{array}{l}\text {-Literature research } \\
\text {-User research } \\
\text {-Statistical research } \\
\text {-Research-based tool development }\end{array}$ \\
\hline $\begin{array}{l}\text { Accumulation of } \\
\text { knowledge }\end{array}$ & $\begin{array}{l}\text { Data collecting and } \\
\text { storage process }\end{array}$ & $\begin{array}{l}\text {-Literature research } \\
\text {-User research } \\
\text {-Patient data record research } \\
\text {-Database } \\
\text { - User feedback } \\
\text {-Machine Learning }\end{array}$ \\
\hline $\begin{array}{l}\text { Identification of } \\
\text { knowledge }\end{array}$ & $\begin{array}{l}\text { Literature research; } \\
\text { data analysis; } \\
\text { interpretation of data }\end{array}$ & $\begin{array}{l}\text {-Literature research } \\
\text {-Data analysis } \\
\text {-Data interpretation }\end{array}$ \\
\hline $\begin{array}{l}\text { Application of } \\
\text { knowledge }\end{array}$ & $\begin{array}{l}\text { The experimental part } \\
\text { of the research }\end{array}$ & $\begin{array}{l}\text {-Development of a tool } \\
\text {-Usability testing } \\
\text {-Approbation of tool }\end{array}$ \\
\hline $\begin{array}{l}\text { Development of } \\
\text { knowledge }\end{array}$ & $\begin{array}{l}\text { Data analysis; results; } \\
\text { interpretation of results }\end{array}$ & $\begin{array}{l}\text {-Data analysis } \\
\text {-Data interpretation and result representation }\end{array}$ \\
\hline $\begin{array}{l}\text { Deepening of } \\
\text { knowledge }\end{array}$ & Results; new theories & $\begin{array}{l}\text {-Result representation } \\
\text {-Use of previous developments as usability testing } \\
\text { and feedback for improvement of the prototype } \\
\text {-AI component incorporation in tool }\end{array}$ \\
\hline $\begin{array}{l}\text { Popularisation of } \\
\text { knowledge } \\
\text { Dissemination of } \\
\text { knowledge }\end{array}$ & $\begin{array}{l}\text { Report writing; present } \\
\text { findings; to } \\
\text { disseminate the results } \\
\text { of research activities in } \\
\text { the form of training, } \\
\text { publications or } \\
\text { knowledge transfer }\end{array}$ & $\begin{array}{l}\text {-Recommendations and methodology } \\
\text {-Technical documentation } \\
\text {-Publications } \\
\text {-Presentations and oral reports } \\
\text {-Conference and discussions } \\
\text { - Report writing } \\
\text {-Doctoral thesis }\end{array}$ \\
\hline $\begin{array}{l}\text { Use of } \\
\text { knowledge }\end{array}$ & $\begin{array}{l}\text { Previous research data, } \\
\text { information, and } \\
\text { knowledge used in } \\
\text { current research: all } \\
\text { from current research } \\
\text { - use in further } \\
\text { research }\end{array}$ & $\begin{array}{l}\text {-Knowledge use from literature research and user } \\
\text { research to recommendation development } \\
\text {-Recommendation use for methodology } \\
\text { development } \\
\text {-Recommendation and methodology used for tool } \\
\text { development } \\
\text {-Artificial Intelligence and Machine Learning } \\
\text {-Suggestions for future steps } \\
\text {-Future research }\end{array}$ \\
\hline
\end{tabular}


Mackare \& Jansone, 2021. Knowledge Management in Artificial Intelligence Based Automated E-Material Formatting Tool

During literature research and development of formatting recommendations and methodology was used declarative knowledge as it was based on facts and relationships among variable from previous methodologies, formatting suggestions and research reports. The same knowledge type is a description of requirements and tools idea, development list of necessary parameters, and concept creation - as there is clear understandability of what needs to be created at the end.

The tool development as creating technical tasks, working schemes, searching for a technical solution, programming, writing of technical documentation is procedural knowledge as those are steps and actions to desired (or undesired) outcomes. The same is developed a prototype and usability testing of the tool as it gives the overview of the tools work, relationships between main edges and the collaboration process with the user, material, and database.

In the development of automatic e-material formatting, the tool has been used both explicit knowledge and tacit knowledge. The result of development also is a process of explicit knowledge creation as an e-material formatting methodology and formatting tool as a computer program. However, as the tool is based on Artificial Intelligence components as Machine Learning, it incorporates experience-based decisions, which result in tacit knowledge as well. It is possible to tell what developed tool based on AI convert explicit knowledge into tacit during the machine learning process.

Theoretically, the tool's tacit knowledge can be converted into explicit knowledge if it will be possible to incorporate this knowledge in the methodology for e-material formatting by formalising that knowledge. It could be one of the future research points: to find tools and methods to convert AI-based tools' created knowledge as individualised e-material formatting to values that could be systematised and described in the user-centred methodology.

The developed methodology for e-material formatting is general knowledge as everyone with a basic understanding of text formatting can understand and use it. So, it could be possessed by many individuals and transferred easily and quickly across individuals.

Technology-specific knowledge is deep knowledge about a specific area automated e-material formatting. It includes knowledge about the developed tool and techniques that are used to made e-material formatting on several different levels and be the user-centric - more individual approach of formatting to solve existing problems of e-material formatting and their effect on users.

AI tools generated formatting suggestions are context-specific knowledge as they refer to a specific user and current situation. This specific knowledge cannot be acquired through AI's formal training by using only standard ML approaches from training-sample use. Instead, those must be obtained from within a specific 
context. That is obtained not only from groups responses but based on the context of individual user needs and preferences, as well as feedbacks.

Actually, it may be called context-and-technology-specific knowledge, as, based on the theoretical bases of KM, there is a need simultaneously involves both - rich scientific knowledge and an understanding of the particular context for correct and smooth work of the tool and high achievements in results.

There has been used a broad range of different knowledge types in research and tool development.

Representation of the Different Types of Knowledge storage and Intellectual capital in research

For most parts of the development and research process are used data, information, and existing knowledge and skills. To reach all needed knowledge in research and development, different locations of knowledge have been used.

Knowledge location or reservoirs used in tool development and research are represented in Table 2. Those are supplemented with related knowledge capital and type of knowledge.

\section{Table 2 Representation of the Different Types of Knowledge Storage and Intellectual Capital in Research}

\begin{tabular}{|l|c|l|}
\hline \multicolumn{1}{|c|}{$\begin{array}{c}\text { Knowledge location or } \\
\text { reservoirs }\end{array}$} & Knowledge capital & Type of Knowledge \\
\cline { 1 - 1 } People & Duman capital & \\
\cline { 1 - 2 } User research & Data for knowledge & Tacit \\
\cline { 1 - 2 } Usability testing & Knowledge and skills & Tacit and explicit \\
\cline { 1 - 2 } Development team & Structural capital & \\
\hline $\begin{array}{l}\text { Previous research, } \\
\text { documentation, } \\
\text { recommendation, } \\
\text { methodologies, statistical data }\end{array}$ & $\begin{array}{l}\text { Data and information for } \\
\text { knowledge and knowledge }\end{array}$ & Explicit \\
\cline { 1 - 1 } Research of similar tools & & \\
\hline
\end{tabular}

Representation of Knowledge Management foundation in research

Broad research requires a lot of data, information, knowledge, and skills. At the same time, it needs supporting mechanisms and technologies that supports and promotes both research and development. It resonates with KM.

The four knowledge management processes and related four KM systems are supplemented with seven relevant subprocesses, and examples of KM Associated Mechanisms and Technologies in the development of tool and research are represented in Table 3. 
Mackare \& Jansone, 2021. Knowledge Management in Artificial Intelligence Based Automated E-Material Formatting Tool

Table 3 KM Processes and Subprocesses and KM systems, and KM Associated Mechanisms and Technologies in Research

\begin{tabular}{|c|c|c|c|c|}
\hline $\begin{array}{c}\text { KM } \\
\text { Processes }\end{array}$ & KM Systems & $\begin{array}{c}\text { KM } \\
\text { Subprocesses }\end{array}$ & $\begin{array}{c}\text { KM Mechanisms } \\
\text { in research }\end{array}$ & $\begin{array}{l}\text { KM Technologies } \\
\text { in research }\end{array}$ \\
\hline \multirow[t]{2}{*}{$\begin{array}{l}\text { Knowledge } \\
\text { Discovery }\end{array}$} & \multirow[t]{2}{*}{$\begin{array}{l}\text { Knowledge } \\
\text { Discovery } \\
\text { systems }\end{array}$} & Combination & $\begin{array}{l}\text { - Documentation } \\
\text { - Development } \\
\text { team's } \\
\text { collaborative } \\
\text { creation of } \\
\text { documentation }\end{array}$ & $\begin{array}{l}\text { - Database of tool } \\
\text { - Web-based } \\
\text { access to data } \\
\text { - Data-mining for } \\
\text { data obtaining } \\
\text { - Repositories of } \\
\text { information } \\
\text { - Web portals for } \\
\text { research purpose } \\
\text { and usability } \\
\text { testing }\end{array}$ \\
\hline & & Socialisation & $\begin{array}{l}\text { - Conferences } \\
\text { - Cooperative } \\
\text { projects }\end{array}$ & $\begin{array}{l}\text { - Video- } \\
\text { conferencing } \\
\text { - e-mail }\end{array}$ \\
\hline \multirow[t]{2}{*}{$\begin{array}{l}\text { Knowledge } \\
\text { Capture }\end{array}$} & \multirow{2}{*}{$\begin{array}{l}\text { Knowledge } \\
\text { Capture } \\
\text { systems }\end{array}$} & Externalisation & $\begin{array}{l}\text { - Prototypes } \\
\text { - Models }\end{array}$ & - Best practices \\
\hline & & Internalisation & $\begin{array}{l}\text { - Learning by } \\
\text { doing }\end{array}$ & $\begin{array}{l}\text { - AI-based } \\
\text { knowledge } \\
\text { acquisition }\end{array}$ \\
\hline \multirow{2}{*}{$\begin{array}{l}\text { Knowledge } \\
\text { Sharing }\end{array}$} & \multirow{2}{*}{$\begin{array}{l}\text { Knowledge } \\
\text { Sharing } \\
\text { systems }\end{array}$} & Socialisation & See above & See above \\
\hline & & Exchange & $\begin{array}{l}\text { - Manuals } \\
\text { - Presentation }\end{array}$ & $\begin{array}{l}\text { - Web-based } \\
\text { access to data } \\
\text { - Database } \\
\text { - Repositories of } \\
\text { information }\end{array}$ \\
\hline \multirow[t]{2}{*}{$\begin{array}{l}\text { Knowledge } \\
\text { Application }\end{array}$} & \multirow[t]{2}{*}{$\begin{array}{l}\text { Knowledge } \\
\text { Application } \\
\text { systems }\end{array}$} & Direction & - Support group & $\begin{array}{l}\text { - Case-based } \\
\text { reasoning } \\
\text { systems }\end{array}$ \\
\hline & & Routines & $\begin{array}{l}\text { - Work practices } \\
\text { - Standards }\end{array}$ & $\begin{array}{l}\text { - Management } \\
\text { information } \\
\text { systems }\end{array}$ \\
\hline
\end{tabular}

\section{Conclusions}

Publication systematically represents knowledge management aspects from the theoretical point of view and description of the case study - artificial intelligence based automated e-material formatting tool development and research accompanying the development of the tool. Knowledge management aspects examples follow it in the case study object.

There are included knowledge management aspects as components of knowledge management definition, types of knowledge, knowledge storage, 
Intellectual capitals, knowledge management processes and related subprocesses, knowledge management systems, knowledge management associated mechanisms and technologies used in the case study.

Analysis of tool development and research shown through knowledge management aspects demonstrated that type of knowledge, tools and sources have been used and what type of knowledge have been created. At the same time, the research and development of the tool used as an example are extensive than could see a broad use of knowledge management aspects.

It allows concluding what knowledge management and research cooperates. On the one hand, knowledge management support research. On the other hand, research provides knowledge management with several elements as data and information for knowledge creation, knowledge for use and creation of new knowledge, and development of new knowledge management and knowledge management processes support technologies.

Research shows that $\mathrm{AI}$ is a support technology for knowledge management, as well as knowledge management is a support approach for AI-based tool development.

Thereby, the publication shows both discipline cooperation and could be used as a sample in the study process to understand knowledge management and knowledge management aspects in research and development through the case study.

\section{References}

Becerra-Fernandez, I., Sabherwal, R., (2010). Knowledge Management: Systems and Processes. M.E. Sharpe Inc., Armonk, New York, USA.

Definition. (n.d.) Explicit knowledge. Definitions.net. STANDS4 LLC, 2021. Web. Retrieved from https://www.definitions.net/definition/explicit+knowledge.

Girard, J. P., Girard, J.A.L., (2015). Defining knowledge management: Toward an applied compendium. Online Journal of Applied Knowledge Managemen, 3(1), 14, 1-20.

KMT. (2018). “Types of Knowledge”. Retrieved from https://www.knowledge-managementtools.net/different-types-of-knowledge.html

Mackare, K., Jansone, A. (2017a). Research of guidelines for designing e-study materials ETR17. Proceedings of the 11th International Scientific and Practical Conference Environment, Technology, Resources, June 15-17, 2017, Rezekne, Latvia, Volume 2, 90-96.

Mackare, K., Jansone, A. (2017b). Recommended formatting parameters for e-study materials. Conference proceeding book of the 3rd International Conference on Lifelong Education and Leadership for All; SEP 12-14, 2017; Porto, PORTUGAL, 514-522.

Mackare, K., Jansone, A. (2018). Recommended formatting parameters for e-study materials. IJLEL JOURNAL, Vol 4, No 1, 8-14.

Mackare, K., Jansone, A., Zigunovs, M. (2018). E-material creating and formatting application. Book series: Advances in Intelligent Systems and Computing 876, Human Systems Engineering and Design: Proceedings of the 1st International Conference on Human 
Mackare \& Jansone, 2021. Knowledge Management in Artificial Intelligence Based Automated E-Material Formatting Tool

Systems Engineering and Design (IHSED2018): Future Trends and Applications, October 25-27, 2018, Reims, France, 135-140

Mackare, K., Jansone, A. (2019a). The concept for e-material creating and formatting application prototype. PEN, Periodicals of Engineering and Natural Sciences, 7(1), 197-204.

Mackare, K., Jansone, A. (2019b). Personalized learning: effective e-material formatting for users without disability or specific limitation, Educational Alternatives, Volume 17, 2019, pp. 194-206, ISSN 1314-7277

Mackare, K., Jansone, A. (2019c). Artificial Intelligence aspects in developed E-material formatting application. Conference proceedings of The International Conference on Artificial Intelligence and Advanced Manufacturing of ACM 2019, October 17-19, 2019, Dublin, Ireland.

Mackare, K., Jansone, A., Konarevs, I. (2019). The prototype version for e-material creating and formatting application. BJMC journal, Vol. 7(2019), No. 3, 383-392.

Mackare, K., Jansone, A., Mackars, R. (2020a). E-material formatting application prototype 2.0 development through usability testing of prototype 1.0. IHSI 2020 Conference Proceeding, 2nd International Conference on Intelligent Human Systems Integration.

Mackare, K., Jansone, A., Mackars, R. (2020b). E-material formatting application prototype 2.0. BJMC journal, Vol. 8 (2020), No. 4, 560-567.

Mackare, K., Jansone, A., Mackars, R. (2020c) Use of Artificial Intelligence and Machine Learning for personalization improvement in developed E-material formatting application. Computing Conference 2020 proceedings published in Springer series In: Arai K., Kapoor S., Bhatia R. (eds) Intelligent Computing. SAI 2020. Advances in Intelligent Systems and Computing, vol 1229. Springer, Cham.

Mackare, K., (2021a). Methodologies for e-material formatting. Unpublished.

Mackare, K., (2021b). Doctoral thesis draft. Unpublished.

Newman, B.D., Conrad, K.W. (2000). A Framework for Characterizing Knowledge Management Methods, Practices, and Technologies. Conference paper: PAKM 2000, Third International Conference on Practical Aspects of Knowledge Management, Proceedings of the Third International Conference, Basel, Switzerland, October 30-31, 2000, 16-1 - 16-11.

Staudinger, U.M., Dörner, J. (2007)., Wisdom, Encyclopedia of Gerontology (Second Edition) 2007, pp. 674-683.

UNC. (2007). Introduction to Knowledge Management. The University of North Carolina at Chapel Hill. Archived from the original on March 19, 2007. Retrieved from www.unc.edu.

Zanjani, M.S., Mehregan, M.R. (2009). Knowledge Management Mechanisms In Programmes, Open access peer-reviewed chapter. Advanced Technologies. DOI: 10.5772/8207

Zigunovs, M., Mackare, K., Jansone, A. (2018). E-learning material adaptive software development. Unpublished. 